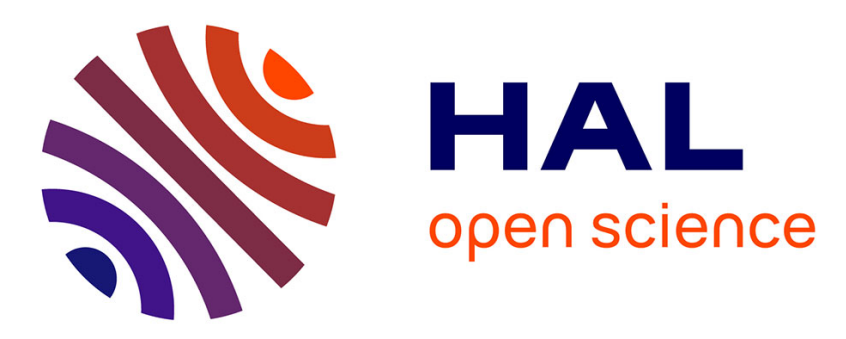

\title{
Lipidic polyols using Thiol-ene/yne strategy for crosslinked Polyurethanes
}

Phuoc Dien Pham, Vincent Lapinte, Yann Raoul, Jean Jacques Robin

\section{To cite this version:}

Phuoc Dien Pham, Vincent Lapinte, Yann Raoul, Jean Jacques Robin. Lipidic polyols using Thiolene/yne strategy for crosslinked Polyurethanes. Journal of polymer science: Part A, General papers, 2014, pp.1597-1606. 10.1002/pola.27159 . hal-01072015

\section{HAL Id: hal-01072015 https://hal.science/hal-01072015}

Submitted on 7 Oct 2014

HAL is a multi-disciplinary open access archive for the deposit and dissemination of scientific research documents, whether they are published or not. The documents may come from teaching and research institutions in France or abroad, or from public or private research centers.
L'archive ouverte pluridisciplinaire HAL, est destinée au dépôt et à la diffusion de documents scientifiques de niveau recherche, publiés ou non, émanant des établissements d'enseignement et de recherche français ou étrangers, des laboratoires publics ou privés. 


\title{
Lipidicpolyolsusing Thiol-ene/yne strategyforcrosslinkedPolyurethanes
}

\author{
Pham P. D., ${ }^{a}$ Lapinte V., ${ }^{a^{*}}$ Raoul Y., ${ }^{b}$ Robin J.-J. ${ }^{a}$
}

a: Institut Charles Gerhardt Montpellier UMR5253 CNRS-UM2-ENSCM-UM1 EquipeIngénierie et Architectures Macromoléculaires, Université Montpellier II - Bat 17 cc1702, Place EugèneBataillon 34095 Montpellier Cedex 5.

b: Société Interoléagineuse d'Assistance et de développement (S.I.A.), 11, rue de Monceau CS 6000375378 Paris cedex 08, France.

Phuoc-Dien.Pham@univ-montp2.fr,

Vincent.Lapinte@univ-montp2.fr, y.raoul@novance.com, Jean-Jacques.Robin@univ-

$\underline{\text { montp2.fr }}$

RECEIVED DATE (to be automatically inserted after your manuscript is accepted if required according to the journal that you are submitting your paper to)

TITLE RUNNING HEAD.Lipidic polyols for polyurethane materials.

CORRESPONDING AUTHOR FOOTNOTE.Institut Charles Gerhardt Montpellier UMR5253 CNRS-UM2-ENSCM-UM1, EquipeIngénierieet Architectures Macromoléculaires, Université Montpellier II cc1702, Place EugèneBataillon. 34095 Montpellier Cedex 5, France.

Tel: 33-4-67-14-48-32; fax: 33-4-67-14-40-28. Vincent.Lapinte@univ-montp2.fr 


\begin{abstract}
Oleic acid and diacid were converted into propargylic esters followed by thiol-ene/yne coupling (TEC/TYC) functionalizationin presence of mercaptoethanol. The multi-radical addition on fatty esters leads to the formation of lipidic polyols ( $\mathrm{OH} 1$ and $\mathrm{OH} 2)$, as judged by ${ }^{1} \mathrm{H}$ NMR and mass spectroscopiesas well as by steric exclusion chromatography (SEC). The crosslinking reaction between TEC/TYC-based polyols and MDI isocyanate reactant was monitored by FTIR experiment and reaction parameters were optimized. By differential scanning calorimetry (DSC), relatively high glass transitions are measured corresponding to structure with little or without dangling chain. Moreover, the thermal stability of the resulting plant oil-based polyurethane materials (PU1 and PU2)were found to be fully consistent with that of other lipidic polyurethanes respectinga three-step process.Thanks to TYC methodology, fatty diacid produces lipidic polyol without dangling chain and lipidic thermoset PU with relatively high $\mathrm{Tg}$.
\end{abstract}

Keywords: fatty acid; polyol; polyurethane; thiol-yne coupling. 


\section{Introduction}

With growing concerns over sustainable development and environmental impact of petrochemical polymer products, researchers are paying more attention to bio-based materials.The main bio-based materials are vegetable oils, polysaccharides, sugars and woods $^{1}$ that are chemically modified for the development of chemicals, plasticizers, ${ }^{2}$ polymers, ${ }^{3}$ blends, ${ }^{4}$ composites, and coatings. ${ }^{5}$ In particular, vegetable oils and their derivatives (fatty alcohols, esters and acids) have been extensively modified to generate bio-based materials ${ }^{6}$ such as polyamides, ${ }^{7}$ non-isocyanate polyurethanes,,${ }^{8,9}$ surfactants, ${ }^{10}$ and epoxy resins. ${ }^{11-13}$

Polyurethanes (PU)sare very interesting polymeric materials allowing a huge variety of industrial applications from paints, coatings, adhesives, sealants and insulation foams. They are synthesized from polyol and poly(isocyanate) reactants producingcarbamate (urethane) bonds. The conversion of unsaturated oils into polyols has been widely investigated to prepare polyurethaneswithdifferentphysical and chemicalproperties.There are severalapproaches to introduce the hydroxyl group into the vegetableoils structure.To date, the synthesis of lipidic polyolshas been mainly accomplished from epoxy vegetable oils or fatty estersintermediate (Table 1). The ring-opening of oxirane by various nucleophiles like alcohol (methanol, ${ }^{14}$ propylene glycol $^{15}$ ) or carboxylic acid (lactic acid ${ }^{16}$ ) was described. An alternative approach consists intheoligomerization of fatty ester by ring-opening of epoxy groups in presence of catalyst based on aluminum. ${ }^{17}$ Ozonolysis of oils and further reduction of terminal acid groups also lead to lipidic polyols. ${ }^{18}$ Cadiz et al. explored another strategy by hydrosilylation of methyl 10-undecenoate with phenyl tris(dimethylsiloxy)silane (PTDS). ${ }^{19}$ Additionally, polyols were prepared by radical pathway: thiol-ene coupling (TEC) using mercaptoethanol in presence of raw oil ${ }^{20}$ or fatty esters. ${ }^{21,22}$ One drawback of plant oil-based PU is the low $\mathrm{Tg}$ value $\left(<40^{\circ} \mathrm{C}\right)$ due to both the low functionality of polyols and the presence of dangling 
chains which act as plasticizers.

Table 1. Comparison of polyols synthesized in this work and in the literature.

\begin{tabular}{|c|c|c|c|c|}
\hline Reference & $\begin{array}{c}\text { Lipidic } \\
\text { precursor }\end{array}$ & Structure & Strategy & Reactant \\
\hline (1) & various $\mathrm{VO}$ & FA & $\begin{array}{l}\text { ROEG and } \\
\text { esterification }\end{array}$ & propylene glycol \\
\hline (2) & soybean & TAG & ROEG & lactic acid \\
\hline (3) & various $\mathrm{VO}$ & TAG & ROEG & methanol \\
\hline (4) & methyloleate & oligomer & $\begin{array}{l}\text { ROEG and } \\
\text { reduction }\end{array}$ & $\mathrm{LiAlH}_{4}$ \\
\hline (5) & various VO & TAG & $\begin{array}{l}\text { ozonolysis and } \\
\text { reduction }\end{array}$ & $\mathrm{O}_{3}$ and $\mathrm{NaBH}_{4}$ \\
\hline (6) & methyloleate & TAG & $\begin{array}{l}\text { hydrosylilation } \\
\text { and reduction }\end{array}$ & $\begin{array}{l}\text { PTDS and } \\
\mathrm{AlLiH}_{4}\end{array}$ \\
\hline (7) & rapeseed oil & TAG & TEC & $\mathrm{HS}-\left(\mathrm{CH}_{2}\right)_{2} \mathrm{OH}$ \\
\hline (8) & methyloleate & FA & allylation + TEC & $\mathrm{HS}-\left(\mathrm{CH}_{2}\right)_{2} \mathrm{OH}$ \\
\hline (9) & methyloleate & FA & $\begin{array}{c}\text { dehydrobromation } \\
+ \text { TYC }\end{array}$ & $\mathrm{HS}-\left(\mathrm{CH}_{2}\right)_{2} \mathrm{OH}$ \\
\hline OH1 & oleate acid & FA & $\begin{array}{c}\text { esterification + } \\
\text { TYC }\end{array}$ & $\mathrm{HS}-\left(\mathrm{CH}_{2}\right)_{2} \mathrm{OH}$ \\
\hline OH2 & oleatediacid & FA & $\begin{array}{l}\text { esterification + } \\
\text { TYC } \\
\end{array}$ & $\mathrm{HS}-\left(\mathrm{CH}_{2}\right)_{2} \mathrm{OH}$ \\
\hline
\end{tabular}


TAG: triacyl glycerol; FA: fatty acid; VO: vegetable oil; ROEG: ring-opening epoxy group; PTDS: phenyl tris(dimethylsiloxy)silane.

Herein, we report a new synthetic approach for the facile synthesis of lipidic polyols viathiolene/yne coupling (TEC/TYC) using 2-mercaptoethanol (Scheme 1). ${ }^{23}$ The TYC splits in two cycle mechanism. ${ }^{24}$ In the first cycle, the thiyl radicals generated from thiol groups were addedon the ethynyl groups to form a vinyl sulfide radical, which could attract a hydrogen atom from a thiol group, producing the vinyl sulfide and generating another thiyl radical at the same time. In the second cycle, a thiyl radical adds on the double bond of the vinyl sulfide, generating a dithioether radical, which attracts a hydrogen atom from a thiol groups and forms the disubstituted product.This synthetic strategy leadsto high-functional polyols since oneethynyl group turns into two thioether groups. By this methodology, propargylic fatty acid (PFE) and diacid (PFD) were converted into lipidic polyols (OH1) and (OH2), respectively.Cadiz et al. havealreadysynthesized lipidic polyols by thiol-yne coupling after bromination, dehydrobromination of 10 -undecenoic and 9-octadecenoic acids. ${ }^{25,26}$ However the ethynyl group is in internal position, along the fatty chain whereas in our case itis in terminal position via propargylic precursor. The advantage of our strategy is to obtain, in the case of diacid, a polyol without dangling chain and plant oil-based PUs with relativelyhigh Tg value. The polyols were carefully characterized by NMR and mass spectroscopies as well as size exclusion chromatography. Finally, crosslinked polyurethanesfrom lipidic polyols $(\mathrm{OH} 1$ and $\mathrm{OH} 2$ )and MDI isocyanate reactant were investigated in terms of thermal properties and stability by DSC and TGA techniques. 


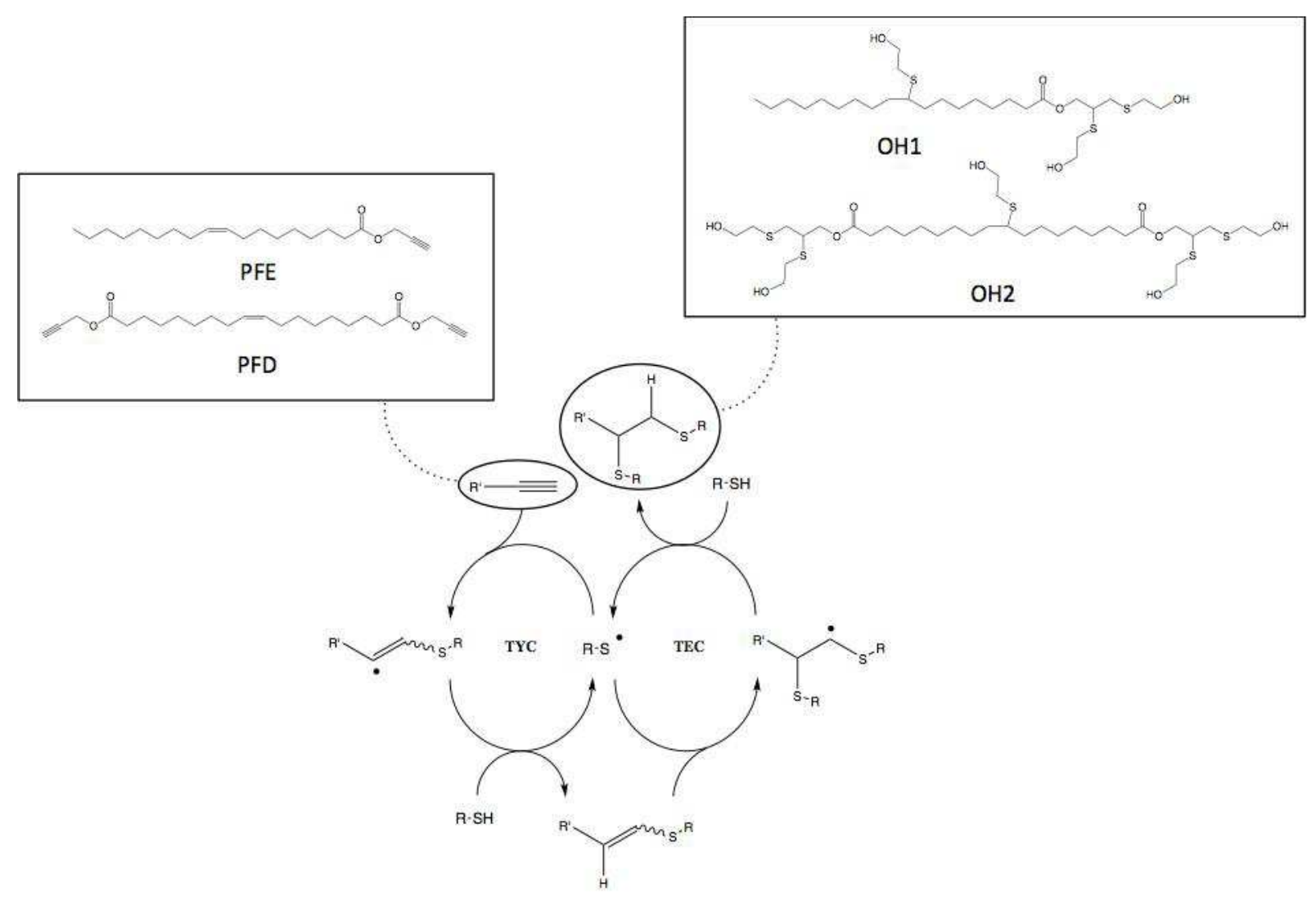

Scheme 1 


\section{Experimental part}

\section{Materials}

Triethylamine, 2-mercaptoethanol, thionyl chloride, propargylic alcohol, 2,2-dimethoxy-2phenylacetophenone (DMPA), oleic chlorideand 4,4'-methylenebis(phenylisocyanate) (MDI) were purchased from Aldrich and were used as received. $N, N$-dimethylformamide (DMF) and chloroform were dried and distilled according to standard procedures. Oleic diacid was generously gifted by S.I.A...Deuterated solvents were purchased from SDS and were used without further purification. 2,2'-Azobisisobutyronitrile (AIBN) was purified twice by recrystallization in methanol and dried under vacuum. Commercially available reagents and solvents were purified and dried, when necessary, by standard methods prior to use.

\section{Analytical Techniques}

${ }^{1} \mathrm{H}$ and ${ }^{13} \mathrm{C}$ NMR spectra were recorded using a Bruker AC 300 and $400 \mathrm{MHz}$ with $\mathrm{CDCl}_{3}$ as solvent. Chemical shifts $\left({ }^{1} \mathrm{H} \mathrm{NMR}\right)$ were referenced to the peak of residual $\mathrm{CHCl}_{3}$ at 7.26 ppm.Chemical shifts $\left({ }^{13} \mathrm{C} \mathrm{NMR}\right)$ were referenced to $\mathrm{CDCl}_{3}$ at $77 \mathrm{ppm}$.Fourier Transform Infrared (FTIR) spectra were recordedwith a Perkin-Elmer Spectrum 100spectrometer equippedwith an attenuated total reflectance (ATR) crystal made ofZnSe.Size exclusion chromatography (SEC) analyses were performed in DMAc $(0.1 \% \mathrm{LiCl})$ as eluent. Two PL-gel mix $\mathrm{C}$ columns were used at $50{ }^{\circ} \mathrm{C}$ with a flow rate of $0.8 \mathrm{~mL} \cdot \mathrm{min}^{-1}$, calibrated using PS standards.Differential scanning calorimetry (DSC) analyses of the samples were carried out on 5-10 mg samples in aluminum pans, using a Mettler Toledo apparatus. The DSC heating and cooling schedules used were as follows: the samples were heated at $10{ }^{\circ} \mathrm{C} \cdot \mathrm{min}^{-1}$ and cooled at the same rate to room temperature. LC/ESI-MS chromatograms were acquired in the positive ion mode with the capillary voltage set at $3000 \mathrm{~V}$ and cone voltage at $30 \mathrm{~V}$ while the 
dry temperature was set at $350{ }^{\circ} \mathrm{C}$ and dry gas flow was maintained at $13 \mathrm{~mL}$. $\mathrm{min}^{-1}$. The mass acquisition range was from m/z 50 to 1000 .The thermo-oxidative stability of the polyurethane materials was examined using a Q50 thermogravimetricanalyzer (TGA) from TA Instruments $^{\circledR}$. The experiments consisted in registering the weight loss of the sample under nitrogen flow $\left(60 \mathrm{~mL} \cdot \mathrm{min}^{-1}\right)$ as a function of temperature from the ambient up to $550{ }^{\circ} \mathrm{C}$. Different experiments were heated at $10{ }^{\circ} \mathrm{C} \cdot \mathrm{min}^{-1}$.

\section{Conversion of oleic diacid into fatty diacid chloride(DCl)}

In a $500 \mathrm{~mL}$ two-necked flask equipped with a refluxcondenser and a dropping funnel, $53.5 \mathrm{~g}$ (171.2mmol) of oleicdiacidwere dissolved in $150 \mathrm{~mL}$ of dry chloroform. The chloroform solution $(200 \mathrm{~mL})$ containingthionyl chloride was added dropwiseover a period of $1 \mathrm{~h}$. The mixture was heated gently on anoil bath held at $60^{\circ} \mathrm{C}$ for 16 hours. The mixture was evaporated under pressure in order to remove any excess of thionyl chloride. The product wasused without any further purification in $97 \%$ yield.

${ }^{1} \mathrm{H}$ NMR $\left(\mathrm{CDCl}_{3}, 300 \mathrm{MHz}\right) \delta(\mathrm{ppm}): 1.16-1.48\left(16 \mathrm{H}, \mathrm{H}_{4-7}, \mathrm{H}_{12-15}\right), 1.55-1.82\left(4 \mathrm{H}, \mathrm{H}_{3}, \mathrm{H}_{16}\right)$, 1.86-2.12 (4H, $\left.\mathrm{H}_{8}, \mathrm{H}_{11}\right), 2.79-2.98\left(4 \mathrm{H}, \mathrm{H}_{2}, \mathrm{H}_{17}\right), 5.25-5.41\left(2 \mathrm{H}, \mathrm{H}_{9}, \mathrm{H}_{10}\right)$.

\section{Synthesis of propargylic esters}

Propargylic alcohol (7.71 g, 137.4mmol) and triethylamine (13.9 g, 137.4mmol) were dissolved in dry dichloromethane $(100 \mathrm{~mL})$. The solution was cooled in an ice bath under $\mathrm{N}_{2}$ for $15 \mathrm{~min}$. At $0{ }^{\circ} \mathrm{C}$, dichloromethane solution $(100 \mathrm{~mL})$ of diacid chloride $(20 \mathrm{~g}, 57.2 \mathrm{mmol})$ was added dropwise to the previous solution over $1 \mathrm{~h}$. The stirring was continued for one additional hour. Then, the mixture refluxed for $16 \mathrm{~h}$. The solution was washed with water $(3 \mathrm{x}$ $200 \mathrm{~mL})$ and brine $(2 \times 100 \mathrm{~mL})$, dried over anhydrous $\mathrm{MgSO}_{4}$, filtered, and evaporated under reduced pressure to yield a brown oil $(19.2 \mathrm{~g}, 86 \%)$. 
Propargylic fatty ester (PFE)

${ }^{1} \mathrm{H}$ NMR $\left(\mathrm{CDCl}_{3}, 300 \mathrm{MHz}\right) \delta(\mathrm{ppm}): 0.79-0.95\left(3 \mathrm{H}, \mathrm{H}_{1}\right), 1.15-1.44\left(20 \mathrm{H}, \mathrm{H}_{2-7}, \mathrm{H}_{12-15}\right)$, 1.52-1.72 (2H, $\left.\mathrm{H}_{16}\right), 1.87-2.11\left(4 \mathrm{H}, \mathrm{H}_{8}, \mathrm{H}_{11}\right), 2.27-2.39\left(2 \mathrm{H}, \mathrm{H}_{17}\right), 2.45-2.50\left(2 \mathrm{H}, \mathrm{H}_{21}\right)$, 4.60-4.72 (4H, $\left.\mathrm{H}_{19}\right), 5.26-5.41\left(2 \mathrm{H}, \mathrm{H}_{9}, \mathrm{H}_{10}\right) .23 .35 \mathrm{~g}, 81 \%$ yield.

${ }^{13} \mathrm{C} \mathrm{NMR}\left(\mathrm{CDCl}_{3}, 100 \mathrm{MHz}\right) \delta(\mathrm{ppm}): 14.04\left(\mathrm{C}_{1}\right), 22.64\left(\mathrm{C}_{2}\right), 24.74\left(\mathrm{C}_{16}\right), 27.10$ and 27.16 $\left(\mathrm{C}_{8}, \mathrm{C}_{11}\right), 28.99-29.72\left(\mathrm{C}_{4-7}, \mathrm{C}_{12-15}\right), 31.87\left(\mathrm{C}_{3}\right), 33.88\left(\mathrm{C}_{17}\right), 51.63\left(\mathrm{C}_{19}\right), 74.61\left(\mathrm{C}_{21}\right), 77.74$ $\left(\mathrm{C}_{20}\right), 129.62$ and $129.89\left(\mathrm{C}_{9}, \mathrm{C}_{10}\right), 172.72\left(\mathrm{C}_{18}\right)$.

FTIR $\left(\mathrm{cm}^{-1}\right): 3312(\mathrm{O}-\mathrm{H}), 2923$ and $2853\left(\mathrm{C}-\mathrm{H}_{\text {stretching }}\right), 1744\left(\mathrm{C}=\mathrm{O}_{\text {ester stretching }}\right)$.

Propargylic fatty diester (PFD)

${ }^{1} \mathrm{H}$ NMR $\left(\mathrm{CDCl}_{3}, 300 \mathrm{MHz}\right) \delta(\mathrm{ppm}): 1.17-1.41\left(16 \mathrm{H}, \mathrm{H}_{4-7}, \mathrm{H}_{12-15}\right), 1.61-1.71\left(4 \mathrm{H}, \mathrm{H}_{3}, \mathrm{H}_{16}\right)$, 1.88-2.08 (4H, $\left.\mathrm{H}_{8}, \mathrm{H}_{11}\right), 2.24-2.40\left(4 \mathrm{H}, \mathrm{H}_{2}, \mathrm{H}_{17}\right), 2.45-2.49\left(2 \mathrm{H}, \mathrm{H}_{21}\right), 4.60-4.70\left(4 \mathrm{H}, \mathrm{H}_{19}\right)$, 5.26-5.38 (2H, $\left.\mathrm{H}_{9}, \mathrm{H}_{10}\right) .19 .2 \mathrm{~g}, 86 \%$ yield.

${ }^{13} \mathrm{C} \mathrm{NMR}\left(\mathrm{CDCl}_{3}, 100 \mathrm{MHz}\right) \delta(\mathrm{ppm}): 24.27\left(\mathrm{C}_{3}, \mathrm{C}_{16}\right), 26.10\left(\mathrm{C}_{8}, \mathrm{C}_{11}\right), 27.97,28.01,28.08$ $\left(\mathrm{C}_{4-7}, \mathrm{C}_{12-15}\right), 32.80\left(\mathrm{C}_{2}, \mathrm{C}_{17}\right), 50.61\left(\mathrm{C}_{19}\right), 73.86\left(\mathrm{C}_{21}\right), 76.85\left(\mathrm{C}_{20}\right), 128.73\left(\mathrm{C}_{9}, \mathrm{C}_{10}\right), 171.51$ $\left(\mathrm{C}_{1}, \mathrm{C}_{18}\right)$.

FTIR $\left(\mathrm{cm}^{-1}\right)$ : $3294(\mathrm{O}-\mathrm{H}), 2926$ and $2854\left(\mathrm{C}-\mathrm{H}_{\text {stretching }}\right), 1739\left(\mathrm{C}=\mathrm{O}_{\text {ester stretching }}\right)$.

Thiol-en/yne coupling (TEC/TYC) between mercaptoethanol and propargylic fatty esters

In a $50 \mathrm{~mL}$ flask, PFD (5 g, $12.86 \mathrm{mmol})$ was reacted with 2-mercaptoethanol (15.07 g, 193 mmol) in presence of the radical initiator DMPA (1.65 g, $6.43 \mathrm{mmol})$ under $\mathrm{N}_{2}$ atmosphere.An amount of $\operatorname{DMF}(2.4 \mathrm{~mL})$ was added todissolve the photoinitiator. The reaction carried out under UV irradiation $(365 \mathrm{~nm})$ at room temperature for $8 \mathrm{~h}$. DMF was then removed under reduced pressure. The mixture was dissolved in $\mathrm{CHCl}_{3}(200 \mathrm{~mL})$, then 
washedwith water $(3 \times 200 \mathrm{~mL})$, and brine $(2 \times 200 \mathrm{~mL})$, dried over anhydrous $\mathrm{MgSO}_{4}$, filtered, and evaporated under reduced pressure to yield a dark yellow oil. The product was purified by column chromatography using $\mathrm{AcOEt} / \mathrm{CH}_{2} \mathrm{Cl}_{2} 3 / 7$, as eluent, to afford a viscous light yellow product $(6.59 \mathrm{~g}, 66 \%)$.

\section{Polyol derivating from $\mathrm{PFE}(\mathrm{OH} 1)$}

${ }^{1} \mathrm{H}$ NMR $\left(\mathrm{CDCl}_{3}, 400 \mathrm{MHz}\right) \square(\mathrm{ppm}): 0.81-1.02\left(3 \mathrm{H}, \mathrm{H}_{1}\right), 1.15-1.76\left(29 \mathrm{H}, \mathrm{H}_{2-16}\right), 2.27-2.44$ $\left(2 \mathrm{H}, \mathrm{H}_{17}\right), 2.53-3.23\left(11 \mathrm{H}, \mathrm{H}_{20}, \mathrm{H}_{21}, \mathrm{H}_{22}, \mathrm{H}_{24}\right), 3.63-3.91\left(6 \mathrm{H}, \mathrm{H}_{23}, \mathrm{H}_{25}\right), 4.06-4.43\left(2 \mathrm{H}, \mathrm{H}_{19}\right)$. ${ }^{13} \mathrm{C} \mathrm{NMR}\left(\mathrm{CDCl}_{3}, 100 \mathrm{MHz}\right) \square(\mathrm{ppm}): 13.52(\mathrm{G}), 22.05\left(\mathrm{C}_{2}\right), 24.23\left(\mathrm{C}_{16}\right), 26.02-29.01\left(\mathrm{C}_{4-8}\right.$, $\left.\mathrm{C}_{12-15}\right), 31.25\left(\mathrm{C}_{3}\right), 32.77\left(\mathrm{C}_{17}\right), 33.56-35.27\left(\mathrm{C}_{9}, \mathrm{C}_{11}, \mathrm{C}_{21}, \mathrm{C}_{22}\right), 44.43\left(\mathrm{C}_{10}\right), 45.32\left(\mathrm{C}_{20}\right)$, 60.54, $60.86\left(\mathrm{C}_{19}, 2 \times \mathrm{C}_{23}\right), 64.77\left(\mathrm{C}_{25}\right), 173.15\left(\mathrm{C}_{18}\right)$.

FTIR (cm $\left.{ }^{-1}\right)$ : $3389(\mathrm{O}-\mathrm{H}), 2930$ and $2858\left(\mathrm{C}-\mathrm{H}_{\text {stretching }}\right), 1736\left(\mathrm{C}=\mathrm{O}_{\text {ester stretching }}\right)$.

\section{Polyol derivating from $\mathrm{PFD}(\mathrm{OH} 2)$}

${ }^{1} \mathrm{H}$ NMR $\left(\mathrm{CDCl}_{3}, 400 \mathrm{MHz}\right) \delta(\mathrm{ppm}): 1.14-1.65\left(27 \mathrm{H}, \mathrm{H}_{2-16}\right), 2.21-2.36\left(4 \mathrm{H}, \mathrm{H}_{2}, \mathrm{H}_{17}\right), 2.64-$ $2.93\left(18 \mathrm{H}, \mathrm{H}_{21}, \mathrm{H}_{22}, \mathrm{H}_{24}\right), 2.99-3.16\left(2 \mathrm{H}, \mathrm{H}_{20}\right), 3.43(\mathrm{OH}), 3.61-3.80\left(10 \mathrm{H}, \mathrm{H}_{23}, \mathrm{H}_{25}\right), 4.13-$ $4.39\left(4 \mathrm{H}, \mathrm{H}_{19}\right)$.

${ }^{13} \mathrm{C} \mathrm{NMR}\left(\mathrm{CDCl}_{3}, 100 \mathrm{MHz}\right) \delta(\mathrm{ppm}): 24.27\left(\mathrm{C}_{3}, \mathrm{C}_{16}\right), 26.06-28.88\left(\mathrm{C}_{4-8}, \mathrm{C}_{12-15}\right), 32.86\left(\mathrm{C}_{2}\right.$, $\left.\mathrm{C}_{17}\right), 33.61,34.36,35.41,32.77\left(\mathrm{C}_{9}, \mathrm{C}_{11}, \mathrm{C}_{21}, \mathrm{C}_{22}\right), 44.51\left(\mathrm{C}_{10}\right), 45.33\left(\mathrm{C}_{20}\right), 60.50,60.84\left(\mathrm{C}_{19}\right.$, $\left.4 \times \mathrm{C}_{23}\right), 64.84\left(\mathrm{C}_{25}\right), 173.20\left(\mathrm{C}_{1}, \mathrm{C}_{18}\right)$.

ESI-MS (m/z): $[\mathrm{M}+\mathrm{H}]^{+}$theo: 779.33 and found: 779.40, $\left[\mathrm{M}-\left(\mathrm{C}_{7} \mathrm{H}_{15} \mathrm{O}_{3} \mathrm{~S}_{2}\right)\right]^{+}$theo: 567.30 and found: 567.3 .

FTIR $\left(\mathrm{cm}^{-1}\right)$ : $3375(\mathrm{OH}), 2931$ and $2856\left(\mathrm{C}-\mathrm{H}_{\text {stretching }}\right), 1731\left(\mathrm{C}=\mathrm{O}_{\text {ester stretching }}\right)$.

\section{General procedure for crosslinked polyurethanes(PU1 and PU2)}


The PU materials were prepared by mixing $\mathrm{OH} 1$ or $\mathrm{OH} 2$ with4,4'-methylenebis(phenyl isocyanate) $(\mathrm{MDI})$ at $60{ }^{\circ} \mathrm{C}$ in an aluminum mold. The $[\mathrm{NCO}] /[\mathrm{OH}]$ ratio ranged from $1 / 1$ to 1.1/1. The vacuum was applied to remove bubbles. The mixture was cured at $60{ }^{\circ} \mathrm{C}$ for $24 \mathrm{~h}$ and post-cured at $110{ }^{\circ} \mathrm{C}$ for $24 \mathrm{~h}$. The resulting PU materials werepeeled off from the mold for characterization tests. 


\section{Results and discussion}

The various approaches described in the literature to synthesize lipidic polyols are summarized in Table 1.Herein, we focus the discussion on the lipidic polyols used in thermoset polyurethanes in presence of MDI isocyanate. Three lipidic structuresare mentioned: i) the triacylglycerols $(\mathrm{TAG})(\mathbf{2}, \mathbf{3}, \mathbf{5}$ and 7), ii) the linear fatty acid derivatives (FA) (1, 8 and 9), and iii) other structures like three-arm stars (6) and oligomers (4). It is interesting to note that the presence of dangling chain was observed in almost all structures, except for $\mathbf{5}$ and $\mathbf{6}$. Otherwise, some structures carry primary alcohol groups $(\mathbf{1}, \mathbf{5}, \mathbf{6}, \mathbf{7}, \mathbf{8}$ and 9) while others carry secondary ones $(\mathbf{2}, \mathbf{3}$ and $\mathbf{4})$. This comparative study also highlights the presence of ester groupin polyol structures apart from4,6,8 and 9. Herein, we proposed two types of polyol based on oleic acid and diacid. From the first one, a triol $(\mathrm{OH} 1)$ bearing an ester group and a dangling chain was elaborated whereas a pentaol $(\mathrm{OH} 2)$ bearing a diester structure without dangling chain was synthesized using fatty diacid.

\section{Synthesis of propargylic fatty ester and diester}

The synthesis of propargylic fatty ester (PFE) and diester (PFD)starts from activated species of oleic (di)acids. The oleic chloride $(\mathrm{OACl})$ is marketed whereas the corresponding diacid (DCl) is easily synthesized in $97 \%$ yield (see experimental part).Thus, the treatment ofOACl and DClwith propargylic alcohol in presence of triethylamine in $\mathrm{CH}_{2} \mathrm{Cl}_{2}$ afforded PFE and PFDinagood yield (81 and 86\%,respectively)(Scheme 2). The complete reaction was monitored by ${ }^{1} \mathrm{H}$ NMR experiment using in both cases the shift of $\mathrm{CH}_{2}-\mathrm{C}=\mathrm{O}$ signal $\left(\mathrm{H}_{17}\right)$ from 2.88 to $2.34 \mathrm{ppm}$ as well as the appearance of the propargylic signals corresponding to $\mathrm{H}_{19}$ and $\mathrm{H}_{21}$ at 4.65 and $2.45 \mathrm{ppm}$. 

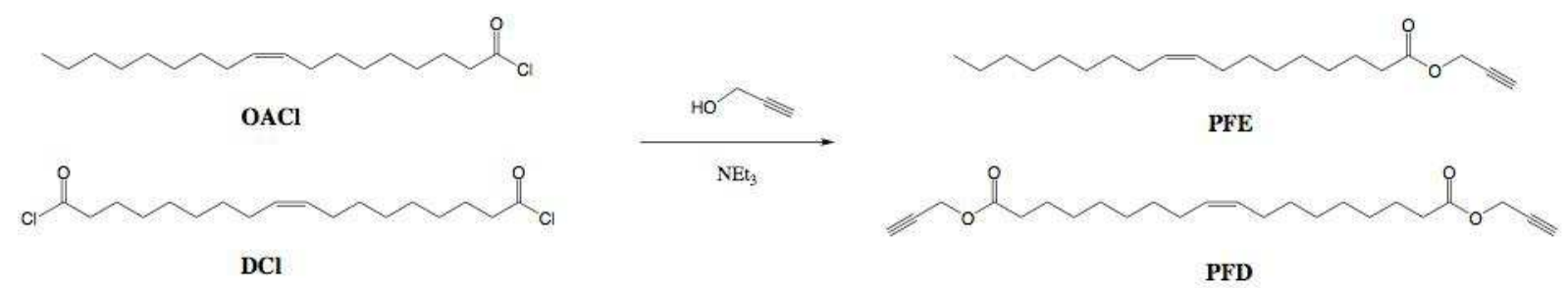

Scheme 2

\section{Photo-inducedthiol-ene/yne reaction for an efficient synthesis of polyols}

To access the highly functional fatty polyols, thiol-ene and thiol-yne couplings could be both associated. In our case, the key step is the functionalization of propargylic fatty (di)esters (PFE and PFD) into fatty polyols ( $\mathrm{OH} 1$ and $\mathrm{OH} 2)$ by photo-inducedthiol-ene/yne coupling (Scheme 1). Mercaptoethanol was both added on internal double bond by thiolenecouplingand terminal propargylic unsaturation by thiol-yne coupling. The photo-induced radical addition of thiol into unsaturation carried out at room temperature in presence of DMPA photoinitiator. Thanks to a simple work-up, the highly functional moieties OH1 (triol) and $\mathrm{OH} 2$ (pentaol) were successfully synthesized in good yields (66-68\%). The ${ }^{1} \mathrm{H}$ NMR spectra confirmed the chemical structure of both polyols as illustrated in Figures 1 and 2. The total consumption of unsaturations: ethylenic $\left(\mathrm{H}_{9-10}\right)$ and propargylic $\left(\mathrm{H}_{19}\right.$ and $\left.\mathrm{H}_{21}\right)$ protons at 5.3, 4.7 and $2.4 \mathrm{ppm}$, respectively was observed in both cases. Moreover, the appearance of signals assigned to $\mathrm{CH}_{2}-\mathrm{OH}$ at 3.6-3.8 ppm $\left(\mathrm{H}_{23}\right.$ and $\left.\mathrm{H}_{25}\right)$ and thioether groups $\left(\mathrm{H}_{20,21,22,24)}\right)$ at 2.55-3.0 ppm attested the mercaptoethanol addition on fatty structures.It is interesting to notify that the both $\mathrm{OH} 1$ and $\mathrm{OH} 2$ polyols are soluble in common solvents such as $\mathrm{CHCl}_{3}$, THF and DMSO and insoluble in water. 


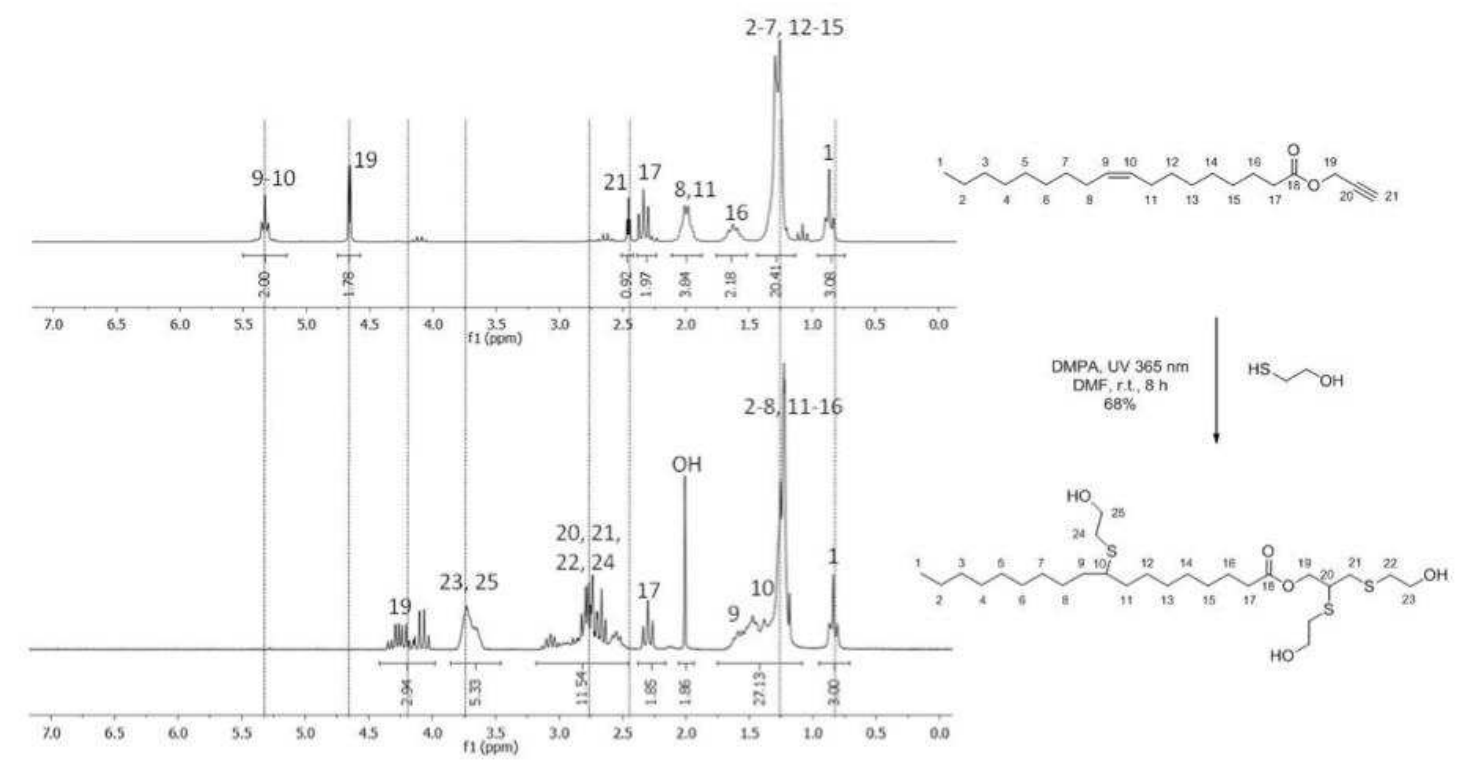

\section{Figure 1}

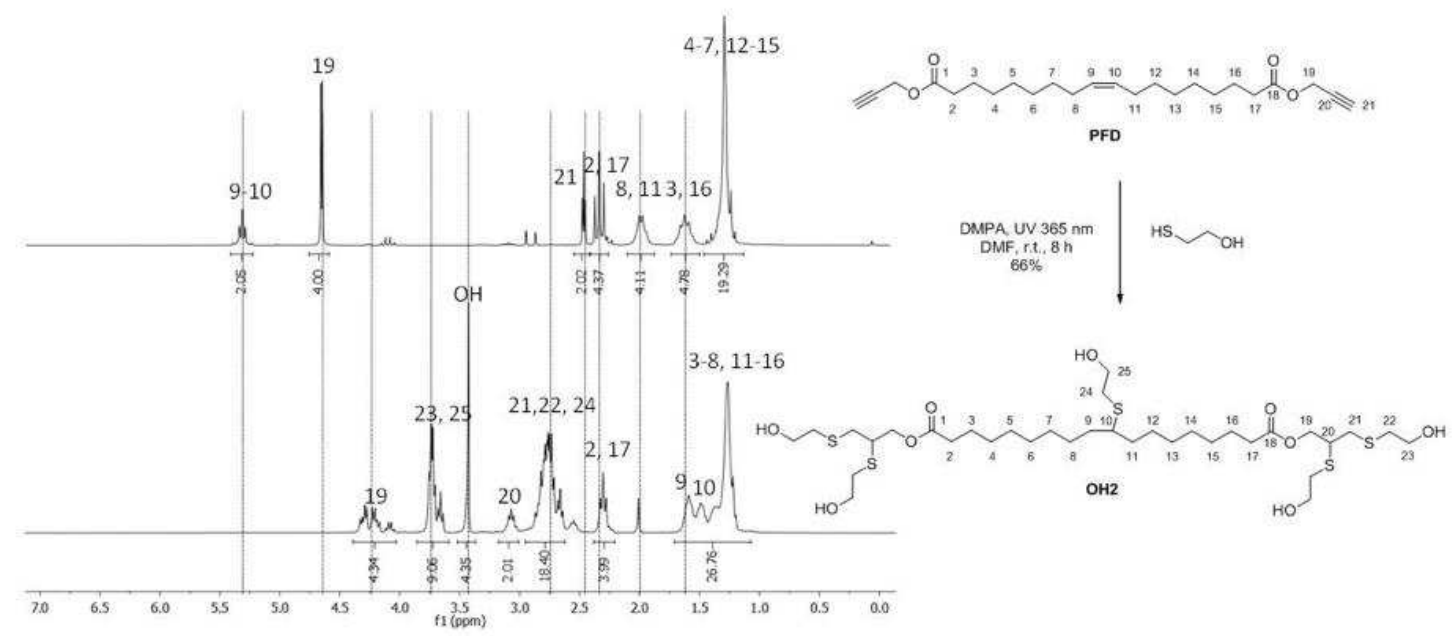

Figure 2

Numeroussynthetic methodologiesof polyols including ring-opening epoxy group, ozonolysis andhydrosylilationwere described in the literature. Unfortunately, in many cases the side reactions accompany the polyol synthesis such as theoligomerization of unsaturated compounds into dimers,trimers, etc. The best way to observe this phenomenon is the utilization of gel permeation chromatography (GPC). By this technique, Curtis et al. detected $17 \%$ of oligomers during the epoxy ring-opening process by lactic acid followed by 
esterification in the case of $\mathbf{2}$,described in Table $1 .{ }^{15}$ Additionally, Pétrovicet al.estimated 18$25 \%$ of oligomers for 3duringoxirane ring-opening reaction of epoxidizedvegetable oil in presence of methanol. ${ }^{14}$ In our case, the formation of oligomers duringthiol-unsaturation coupling was detected by GPC using DMAc and polystyrene standards (Figure 3). We noted that the difference between propargylic ester and diester structure is good enough to be detected by this technique and obviously the modification of PFE and PFD by thiol-ene/yne coupling. First, the synthesis of $\mathrm{OH} 1$ polyol happened withoutoligomer formationsince no trace was observed at higher retention time and a singleGPC tracewas detected with a polydispersity index of 1.03 .For $\mathrm{OH} 2$ polyol, very little oligomers likely dimers appeared as evidenced by the polydispersity index of 1.12 . In addition, the shift of the polyoltraces related than those of PFD and PFEprecursors confirmed the"clicking" of three and five mercaptoethanol units into fatty structures. GPC analysis of $\mathrm{OH} 1$ and $\mathrm{OH} 2$ show an increase in molecular weight from 400 and $500 \mathrm{~g} \cdot \mathrm{mol}^{-1}$ to 1400 and $2400 \mathrm{~g} \cdot \mathrm{mol}^{-1}$. The large difference between targeted and experimental molecular weights could be explained by the use of inappropriate polystyrene standards.

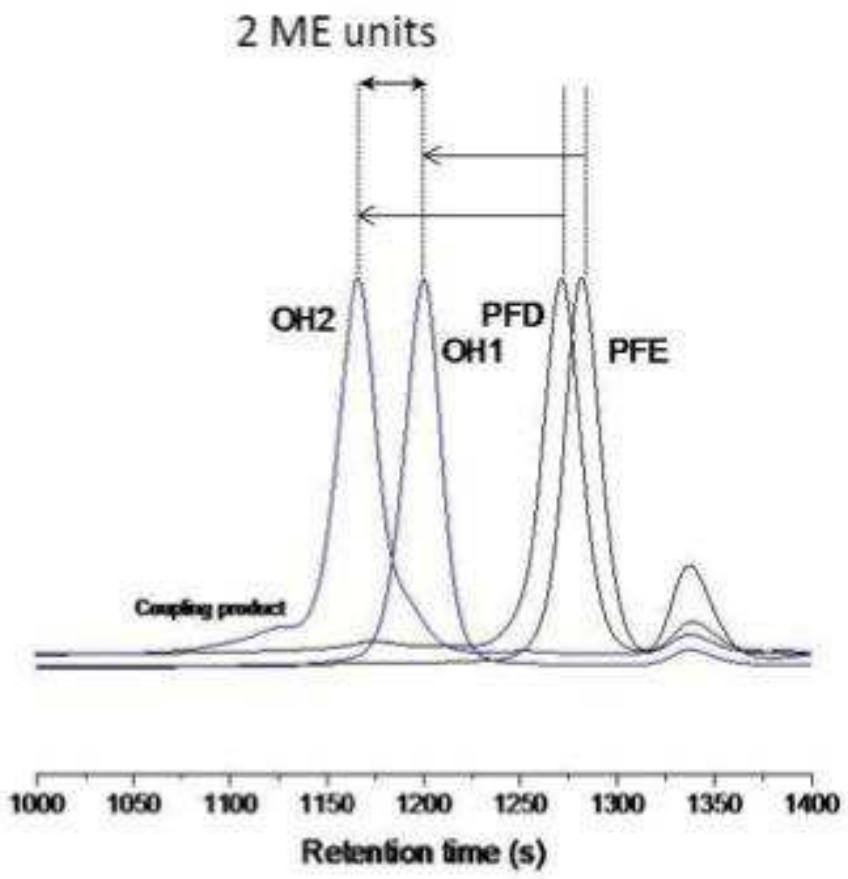

Figure 3 
The structure of $\mathrm{OH} 2$ polyol, alcohol highest functionality of both synthesized,was also explored by LC-ESI/MS technique. As expected, the isomolecular pic $[\mathrm{M}+\mathrm{H}]^{+}$was detected at $\mathrm{m} / \mathrm{z}$ of 779.40 in accordance with the $\mathrm{m} / \mathrm{z}$ theoretical value of 779.33 . Another pic was observed at $\mathrm{m} / \mathrm{z}$ of 567.3 and corresponds to $[\mathrm{M}-211]^{+}$, outcome of the breaking of the C-O bond's breaking of one of the two estergroup.

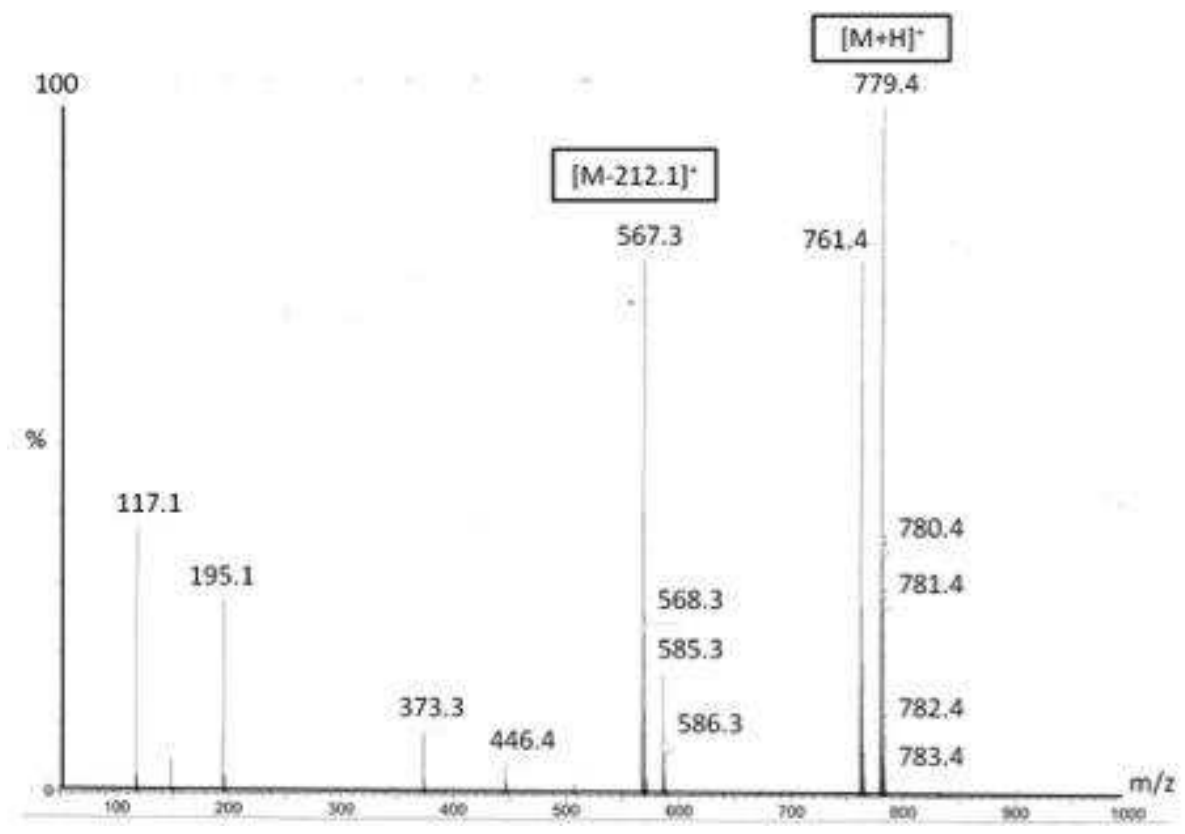

Figure 4

\section{Preparation of PU materials based on lipidic polyols}

The polyol structure obviously impacts the density of polyurethane network. Therefore, the $\mathrm{Tg}$ values and the thermal properties of the thermosets are influenced by the lipidic polyol structures described in Table 1. It is widespread that the dangling chains of the fatty polyols affect the physical properties of the resulting materials and act as plasticizers decreasing the their Tg values. ${ }^{18}$ Apart from $\mathbf{5}$ and $\mathbf{6}$, the polyols described in the literature carry one $(\mathbf{1}, \mathbf{8}$ and 9), three (2, 3and 8) or numerous (4) dangling chains as illustrated in Scheme 3.The design of our vegetable oil based polyols considers this aspect. Thus, thanks to fatty acid and diacid 
precursorscoming from oleic chain, $\mathrm{OH} 1$ and $\mathrm{OH} 2$ polyols were provided with one or without dangling chain using a simple and versatile thiol-ene/yne coupling approach.
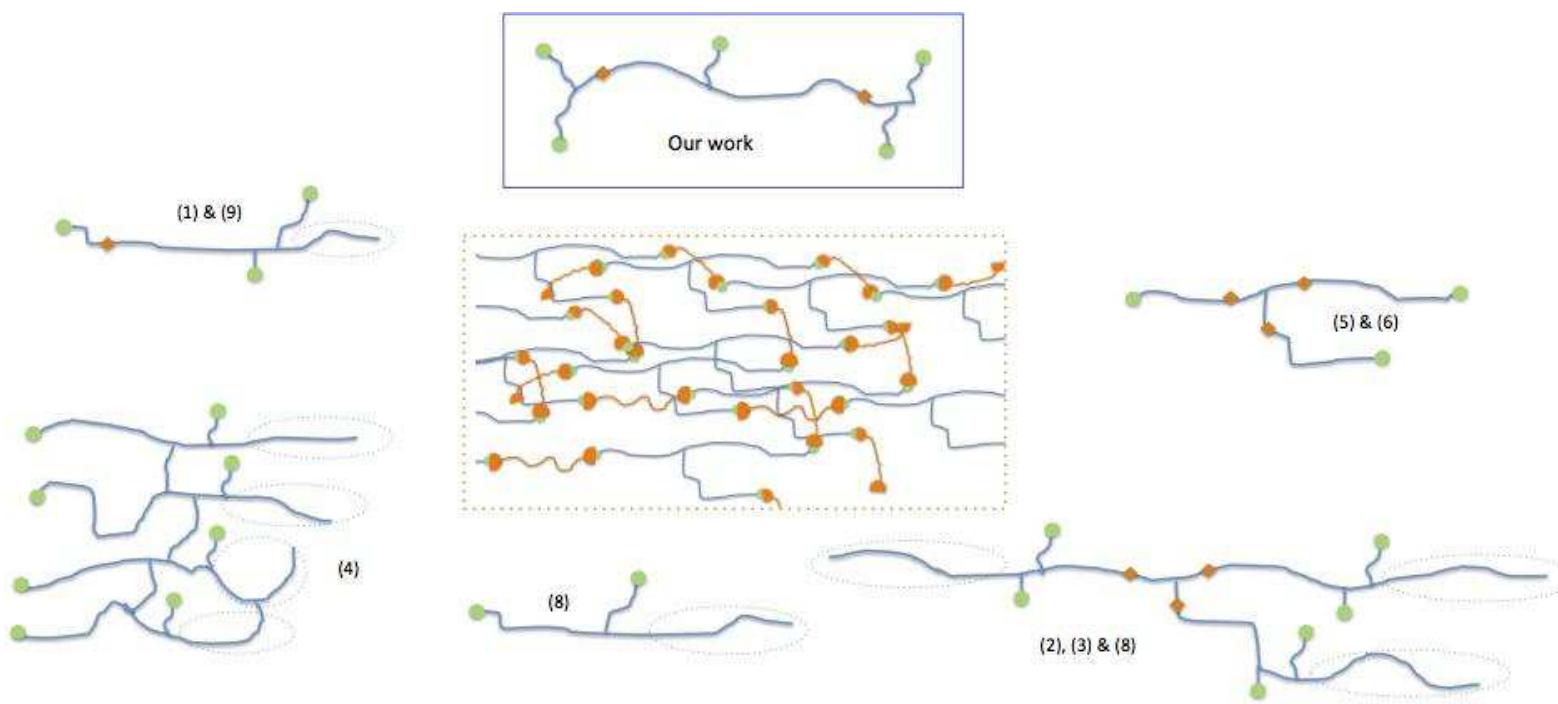

Scheme 3

The comparative study gathers the thermoset polyurethanes coming from MDI and various polyols as compiled in Table 2. The relationship between the polyol structure and the $\mathrm{Tg}$ value of the resulting material was discussed. The Tg valueswere affected by the number of alcohol groups ofeach fatty chain. This value is directly related to the number of double bonds ofprecursors fatty chains. Note that the fatty chains are classified according to the number of carbon atoms (n) and of double bonds (m)such as Cn:m.For 1, 3 and $\mathbf{5}$ polyols, several types of vegetable oils are employed carrying various contents in oleic (C 18:1), linoleic (C 18:2) and linolenic (C 18:3) chains. ${ }^{14,15,18}$ For instance, 3-based PU using canola oil (iodine index of 114) or linseed oil (iodine index of 182) have got a $\mathrm{Tg}$ value of 32 and $77{ }^{\circ} \mathrm{C}$, respectively. ${ }^{14}$ In short, as expected, the high level of unsaturations (iodine index closed to 220) favors the high $\mathrm{Tg}$ value in relation to the crosslinking density. The $\mathrm{Tg}$ values also depend on the strategy of incorporation of alcohol groups on fatty chains (TEC, ring-opening (RO) of 
oxirane). For instance, even if in all cases, fatty precursors are vegetable oils (TAG structure), PU based on 2(RO),3(RO)and 7(TEC) offered a large panel of Tg values ranging from $25^{\circ} \mathrm{C}$ for 7 until $96{ }^{\circ} \mathrm{C}$ for $2 .{ }^{14,16,20}$ Thus, the nature of the functional alcohol unit (lactic acid for 2andmethanol for $\mathbf{3}$ ) added on epoxidized vegetable oil influenced the Tg value.Interestingly, the three-arm star structure (5 and 6) having a terminal alcohol group exhibited low Tg values ranging from 22 and $39{ }^{\circ} \mathrm{C} .{ }^{18,19}$ This result can be explained by the flexibility of the alkyl chainbearing alcohol group and the long distance between two reactive alcohol functions producing a network with wide mesh.

As mentioned above, the presence of dangling chain in polyol structure decreasedthe Tg value by plasticization the Tg value. Besides the oligomer nature of 7, low Tg values were measured $\left(-3\right.$ and $57^{\circ} \mathrm{C}$ ) likely caused by the dangling chain. ${ }^{27} \mathrm{By}$ TEC functionalization, the same problem occurred with modified TAG (7) and modified fatty acid $(\mathbf{8}) .^{20,21}$ The $\mathrm{Tg}$ values varied between 25 and $56^{\circ} \mathrm{C}$. Surprisingly, the structure 1 exhibited the highest Tg value (114 ${ }^{\circ} \mathrm{C}$ ) with 3 alcohol groups ( 2 secondary and 1 primary) with one danglingchain. ${ }^{15}$ In order to enhance the alcohol density in polyol structure without dangling chain, Cadiz et al. reported the thiol-yne functionalization of 10-undecynoic and 9-octadecynoic acids after bromation of double bond, deshydrobromation into alkenic bond followed byesterification of acid group. ${ }^{25}$ The resulting PU thermosets have a Tg value up to $59{ }^{\circ} \mathrm{C}$. In our methodology, even if we kept TYC approach, a shorter strategy was used to incorporatean alkenyl group in fatty acid (PFE) and diacid (PFD) structures. Unlike Cadiz, thiol-ynecoupling led the introduction of terminal alkenyl group by esterification instead of bromation/deshydrobromation of internal double bond. 
Table 2.Comparison of polyurethanes synthesized in this work and in the literature.

\begin{tabular}{|c|c|c|c|}
\hline Reference & {$[\mathrm{NCO}] /[\mathrm{OH}]$} & $\begin{array}{l}\mathbf{T g} \\
\left({ }^{\circ} \mathbf{C}\right)\end{array}$ & $\begin{array}{c}\mathbf{T}_{5 \% \text { loss }} \\
\left({ }^{\circ} \mathbf{C}\right)\end{array}$ \\
\hline (1) & $1.1 / 1$ & $69-114^{c}$ & --- \\
\hline (2) & $1.05 / 1$ & $96^{\mathrm{b}}$ & $273^{\mathrm{e}}$ \\
\hline (3) & 1.02 / 1 & $30-77^{b}$ & --- \\
\hline (4) & $1.02 / 1$ & $-3-57^{d}$ & $337-352$ \\
\hline (5) & $1.02 / 1$ & $22 \& 36$ & $330 \& 337^{\mathrm{e}}$ \\
\hline (6) & $1.02 / 1$ & 39 & $322^{\mathrm{f}}$ \\
\hline (7) & $1.05 / 1$ & $25^{\mathrm{a}}$ & --- \\
\hline (8) & $1 / 1$ & $8-56$ & $269-290$ \\
\hline (9) & $1 / 1$ & $42-59$ & 245 \\
\hline \multirow[t]{2}{*}{ PU1 } & $1 / 1$ & 36 & 297 \\
\hline & $1.1 / 1$ & 45 & 295 \\
\hline \multirow[t]{2}{*}{ PU2 } & $1 / 1$ & 68 & 279 \\
\hline & $1.1 / 1$ & 72 & 282 \\
\hline
\end{tabular}

The thermoset polyurethane materials were prepared by mixing $\mathrm{OH} 1$ or $\mathrm{OH} 2$ with4,4'methylenebis(phenyl isocyanate) (MDI) at $60{ }^{\circ} \mathrm{C}$ in aluminum mold. The mixture was cured at $60{ }^{\circ} \mathrm{C}$ for $24 \mathrm{~h}$ and post-cured at $110^{\circ} \mathrm{C}$ for $24 \mathrm{~h}$. The $[\mathrm{NCO}] /[\mathrm{OH}]$ ratio ranged from $1 / 1$ to 1.1/1 being careful to keep the NCO amount superior than $\mathrm{OH}$ amount in order to compensate the consumption of NCO species by side reactions. The polyurethane crosslinking was confirmed by FTIR analysisas illustrated by the overlapping of $\mathrm{OH} 1$, MDI and PU1 spectra in Figure 5. The total disappearance of $-\mathrm{N}=\mathrm{C}=\mathrm{O}$ stretching of the isocyanate moiety at $2240 \mathrm{~cm}^{-1}$ in PU1 means that the network was complete.Furthermore, the stretching vibration of $\mathrm{C}=\mathrm{O}$ urethane appeared at $1708 \mathrm{~cm}^{-1}$ and overlapped with the $\mathrm{C}=\mathrm{O}$ ester band at $1736 \mathrm{~cm}^{-1}$. The N$\mathrm{H}$ deformation as well as $\mathrm{C}-\mathrm{N}$ stretching vibration occurred at 1520 and $1215 \mathrm{~cm}^{-1}$, respectively. In addition, the broad band at $3500 \mathrm{~cm}^{-1}$ corresponding to $\mathrm{O}-\mathrm{H}$ stretching, shifted to lower frequencies at $3350 \mathrm{~cm}^{-1}$, characteristic of N-H stretching. 


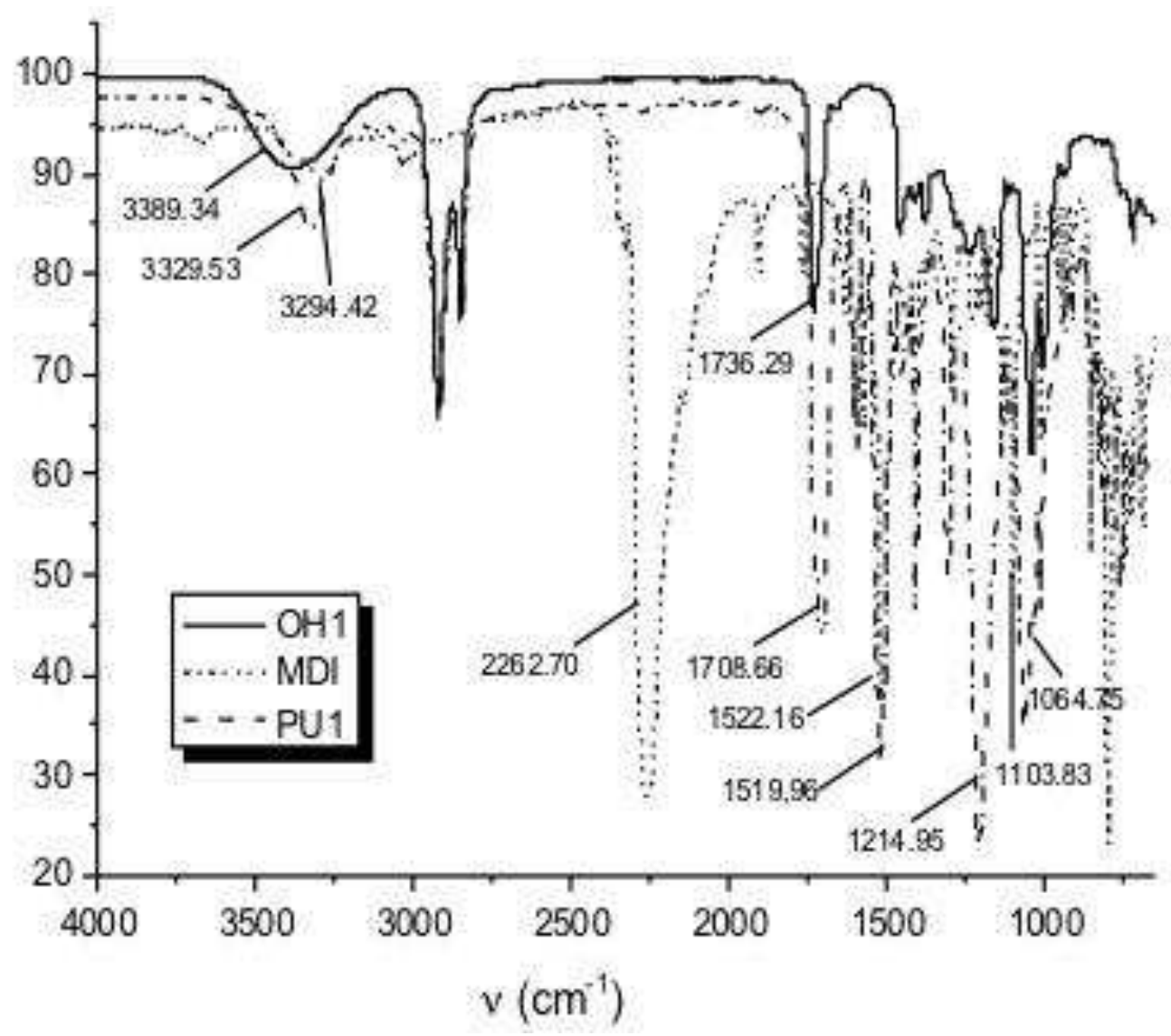

Figure 5

The thermal behaviors of PU1 and PU2 coming from $\mathrm{OH} 1$ and $\mathrm{OH} 2$ were investigated by DSC technique as shown in Figure 6. First, the glass transition temperatures of lipidic polyols (beforecrosslinking) were estimated.The $\mathrm{Tg}$ of $\mathrm{OH} 1$ and $\mathrm{OH} 2$ polyols were found to be -70 and $-58{ }^{\circ} \mathrm{C}$, respectively (Figure 6 , left). The larger number of alcohol groups reduced the mobility of fatty chain and increased the Tg value. Secondly, the same experiments were conducted on resulting thermoset PUs (Figure 6, right). The influence of $[\mathrm{NCO}] /[\mathrm{OH}]$ ratio on the crosslinking density and the Tg value was also investigated and reported in Table 2 . For both polyols, the best results were observed for slight excess in isocyanate: $1.1 / 1$ related than 1/1 as widely described in the literature.It is noteworthy that higher Tg value was measured for PU2in comparison to PU1 (72and45 ${ }^{\circ} \mathrm{C}$, respectively). This differencecould be explained by the presence of dangling chain in the structure of $\mathrm{OH} 1$ in opposition to $\mathrm{OH} 2$ as well as the 
densification of the networkresulting in higher functionality in alcohol groups in the latter case.

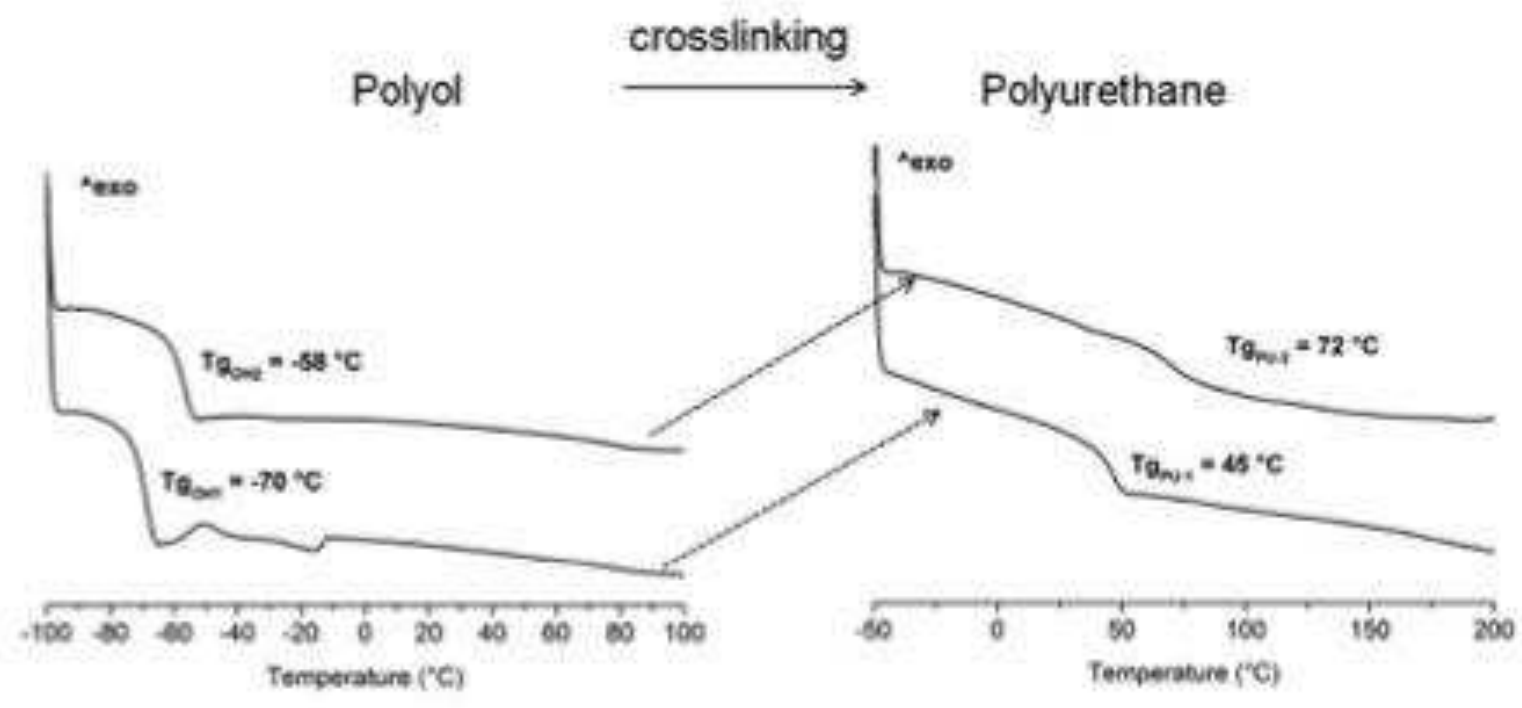

Figure 6

The thermal stability of PU1 and PU2thermosets was investigated bythermogravimetric analysis (TGA) in nitrogen stream, and the results were collected in Figure7. As previously reported, the thermal stability of polyurethanesis relatively low. Our results were in accordance with other thermoset PUs coming from lipidic polyols and synthesized by TEC or TYC methodology. At weightlossof 5\%, the degradation temperatures of PU1 and PU2 were 295 and $282{ }^{\circ} \mathrm{C}$, respectively whereas those of Cadiz are $269-290{ }^{\circ} \mathrm{C}$ for TEC-based polyol (8) and $245{ }^{\circ}$ Cfor TYC-based polyol (9) (Table 2). ${ }^{21,25}$ Moreover, the well-known thermal degradation ofpolyurethanes undergoes in a three-step process. ${ }^{21}$ As described, our productsdegraded in two overlapping steps: i) the first step around $325^{\circ} \mathrm{C}$ resultsin the degradation of weak urethane bondsthrough the dissociation to isocyanate and alcohol and ii) the second step occurs at $343^{\circ} \mathrm{C}$ and corresponds to the decomposition and the char formation of crosslinked polymer networks. Finally, the third decomposition took place at 428$468^{\circ}$ Cand corresponds to the gasification of any remaining components. 

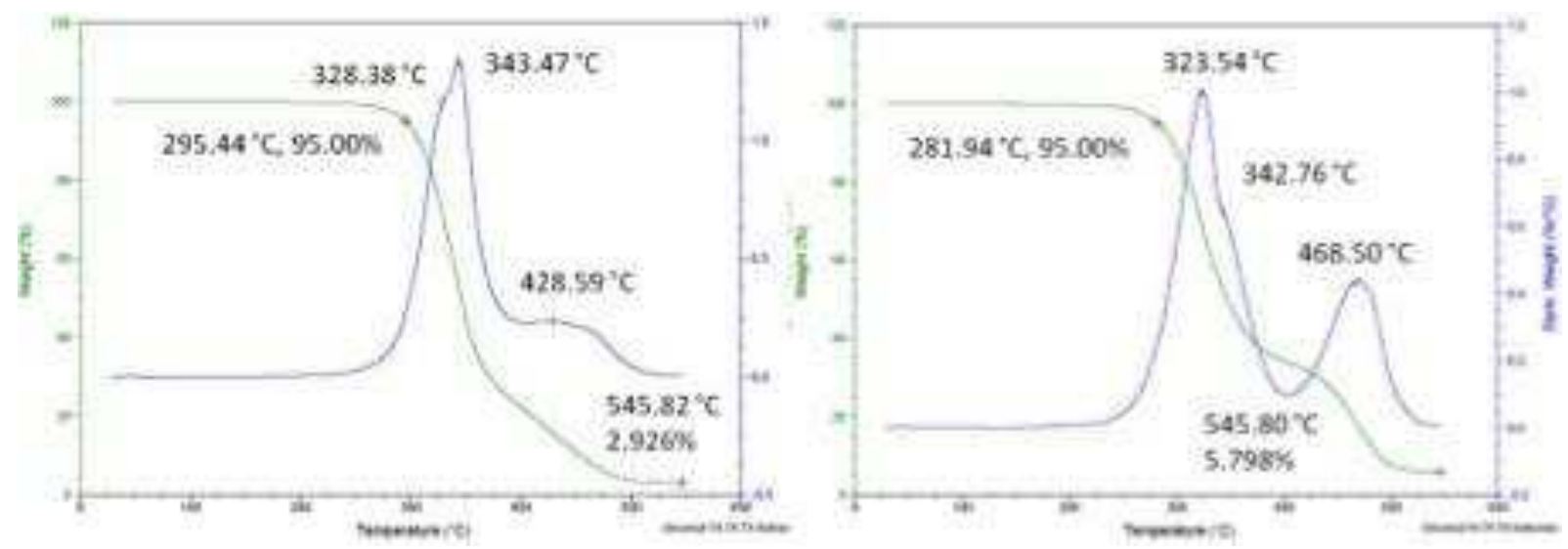

Figure 7

\section{Conclusion}

In this contribution, propargylic fatty acid and diacid were synthesized in good yields. We showed that thiol-ene/yne coupling is an effective approach to synthesize lipidic polyols without oligomers. Foroleicdiacid, polyol without dangling chain was prepared and produced polyurethane materials with $\mathrm{Tg}$ valueof $72^{\circ} \mathrm{C}$ after optimization of the crosslinking parameters (temperature and $[\mathrm{NCO}] /[\mathrm{OH}]$ ). Comparing our results to those reported in the overview regarding toplant oil-based crosslinkedpolyurethanes,we showeda typical thermal stability in a three-step process of plant oil-based thermoset polyurethanes. Thus, through the synthesis of these lipidic polyols, we illustratedthe opportunity of TYC/TECfunctionalization in the synthesis of high functional monomers and branched polymers using bio-based building blocks.

\section{Acknowledgement}

The authors gratefully acknowledge S.I.A. for their financial support. 


\section{References}

(1) Gandini, A. Macromolecules2008, 41, 9491.

(2) Derksen, J. T. P.; Petrus Cuperus, F.; Kolster, P. Progress in Organic Coatings1996, 27, 45.

(3) Yu, L.; Dean, K.; Li, L. Progress in Polymer Science2006, 31, 576.

(4) Vieira, M. G. A.; da Silva, M. A.; dos Santos, L. O.; Beppu, M. M. European Polymer Journa/2011, 47, 254.

(5) Alexandridis, P. Current Opinion in Colloid \& Interface Science1996, 1, 490.

(6) Seniha Güner, F.; Yağcl, Y.; Tuncer Erciyes, A. Progress in Polymer Science2006, 31, 633.

(7) Rybak, A.; Meier, M. A. R. Green Chemistry2007, 9, 1356.

(8) Kathalewar, M. S.; Joshi, P. B.; Sabnis, A. S.; Malshe, V. C. RSC Advances2013, 3, 4110.

(9) Benyahya, S.; Habas, J.-P.; Auvergne, R.; Lapinte, V.; Caillol, S. Polymer International 2012, 61, 1666.

(10) Stemmelen, M.; Travelet, C.; Lapinte, V.; Borsali, R.; Robin, J.-J. Polymer Chemistry 2013, 4, 1445.

(11) Gandini, A. In Epoxy Polymers; Wiley-VCH Verlag GmbH \& Co. KGaA: 2010, p 55.

(12) Stemmelen, M.; Pessel, F.; Lapinte, V.; Caillol, S.; Habas, J. P.; Robin, J. J. Journal of Polymer Science Part A: Polymer Chemistry2011, 49, 2434.

(13) Tan, S. G.; Chow, W. S. Polymer-Plastics Technology and Engineering2010, 49, 1581.

(14) Zlatanić, A.; Lava, C.; Zhang, W.; Petrović, Z. S. Journal of Polymer Science Part B: Polymer Physics2004, 42, 809.

(15) Kong, X.; Liu, G.; Qi, H.; Curtis, J. M. Prog. Org. Coat.2013, 76, 1151.

(16) Miao, S.; Zhang, S.; Su, Z.; Wang, P. J. Polym. Sci., Part A: Polym. Chem.2010, 48, 243.

(17) Del Rio, E.; Galià, M.; Cádiz, V.; Lligadas, G.; Ronda, J. C. Journal of Polymer Science Part A: Polymer Chemistry2010, 48, 4995.

(18) Petrović, Z. S.; Zhang, W.; Javni, I. Biomacromolecules2005, 6, 713.

(19) Lligadas, G.; Ronda, J. C.; Galia, M.; Cadiz, V. Biomacromolecules2006, 7, 2420.

(20) Desroches, M.; Caillol, S.; Lapinte, V.; Auvergne, R. m.; Boutevin, B. Macromolecules 2011, 44, 2489.

(21) González-Paz, R. J.; Lluch, C.; Lligadas, G.; Ronda, J. C.; Galià, M.; Cádiz, V. Journal of Polymer Science Part A: Polymer Chemistry2011, 49, 2407.

(22) Türünç, O.; Meier, M. A. R. Macromolecular Rapid Communications2010, 31, 1822.

(23) Yao, B.; Sun, J.; Qin, A.; Tang, B. Chin. Sci. Bull.2013, 58, 2711.

(24) Fairbanks, B. D.; Scott, T. F.; Kloxin, C. J.; Anseth, K. S.; Bowman, C. N. Macromolecules2008, 42, 211.

(25) Gonzalez-Paz, R. J.; Lligadas, G.; Ronda, J. C.; Galia, M.; Cadiz, V. Polymer Chemistry 2012, 3, 2471.

(26) Lligadas, G. Macromolecular Chemistry and Physics2013, 214, 415.

(27) Del, R. E.; Lligadas, G.; Ronda, J. C.; Galia, M.; Cadiz, V. J. Polym. Sci., Part A: Polym. Chem.2010, 48, 5009. 


\section{Table captions}

Table 1. Comparison of polyols synthesized in this work and in the literature.

Table 2.Comparison of polyurethanes synthesized in this work and in the literature.

\section{Scheme captions}

Scheme 1.General mechanism of thiol-ene andthiol-yne couplings between alkene and alkyne and thiol - Application to PFE and PFD and mercaptoethanol.

Scheme 2. Synthesis of propargylic fatty ester: PFE and PFD.

Scheme 3. Schematic network based on various architectures of lipidic polyols.

\section{Figure captions}

Figure 1. ${ }^{1} \mathrm{H}$ NMR spectra of $\mathrm{PFE}$ and $\mathrm{OH} 1$ in $\mathrm{CDCl}_{3}$.

Figure 2. ${ }^{1} \mathrm{H}$ NMR spectra of $\mathrm{PFD}$ and $\mathrm{OH} 2$ in $\mathrm{CDCl}_{3}$.

Figure 3. GPC traces in DMAcof PFE and PFD precursors and $\mathrm{OH} 1$ and $\mathrm{OH} 2$ polyols.

Figure 4.LC ESI/MS spectrum of PFD.

Figure 5. FTIR spectra of $\mathrm{OH} 1$, MDI and $\mathrm{PU} 1(\mathrm{NCO} / \mathrm{OH}=1.1)$.

Figure 6.DSC thermograms of thermoset polyurethanes (right) and the $\mathrm{OH} 1$ and $\mathrm{OH} 2$ precursors (left).

Figure 7.TGA chromatograms of PU1 (left) and PU2 (right) under nitrogen. 


\section{Graphical abstract}

Lipidic polyols using Thiol-ene/yne strategy for crosslinked Polyurethanes

Phuoc Dien Pham, Vincent Lapinte,* Yann Raoul, Jean-Jacques Robin

Oleic acid and diacid were converted into lipidic polyols by thiol-ene/yne coupling. They are fully characterized before crosslinked into polyurethane materials. Relatively high-Tg polyurethanes are yielded.

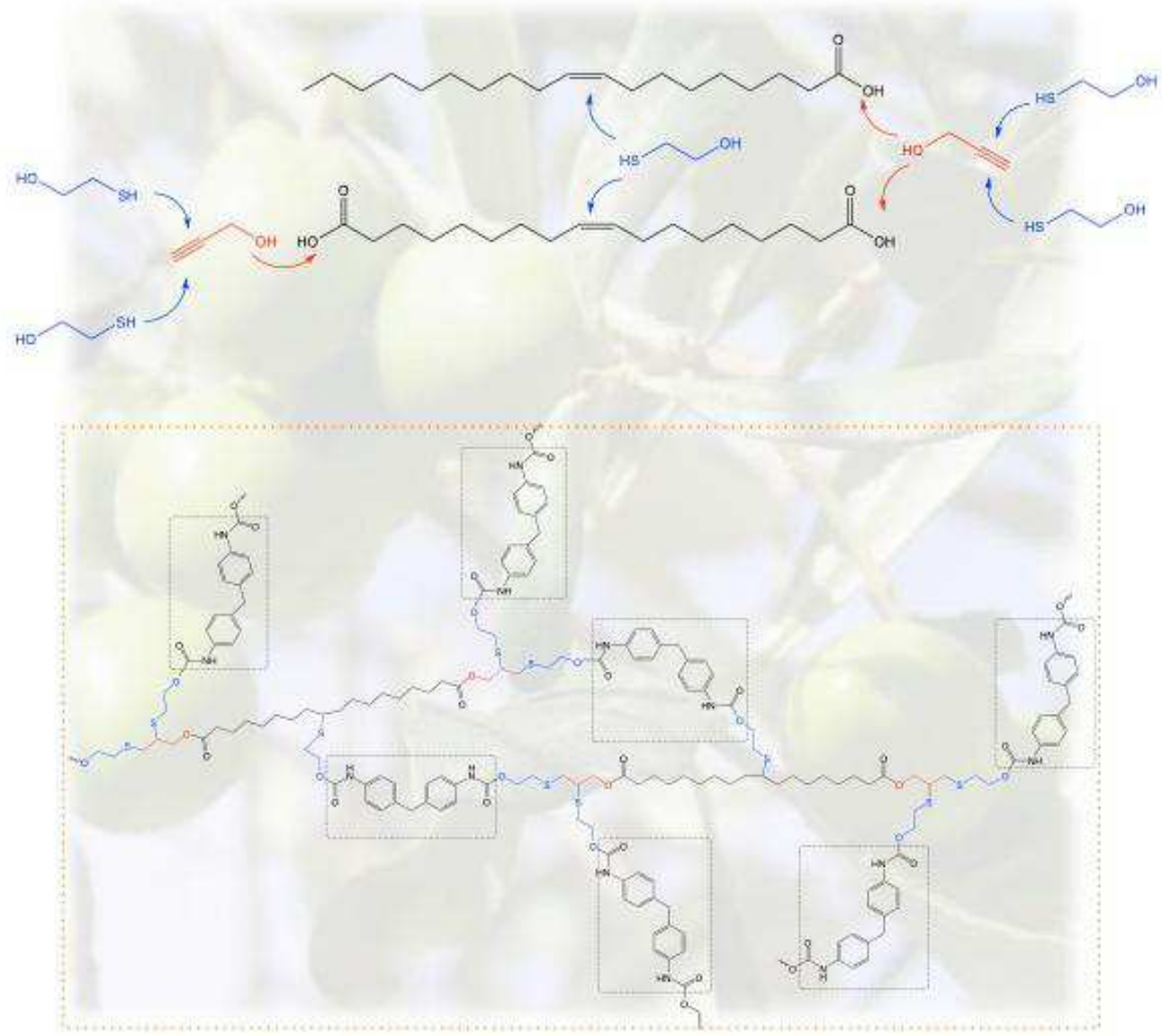

